ROCZNIKI HUMANISTYCZNE

Tom LXIX, zeszyt $1-2021$

DOI: https://doi.org/10.18290/rh21691-8

\title{
„OTÓŻ MOJA URSZULKO TAK SZCZEGÓŁOWY MASZ OPIS \\ MOJEGO TU ŻYCIA, ŻE SĄDZĘ J. J. ROUSSEAU Z RÓWNĄ SZCZEROŚCIĄ NIE PISAŁ SWOICH SPOWIEDZI" - OBRAZY ŻYCIA PRYWATNEGO I KULTURALNEGO W LATACH CZTERDZIESTYCH XIX WIEKU NA PODSTAWIE KORESPONDENCJI GUSTAWA ZIELIŃSKIEGO
}

\begin{abstract}
Świat, ludzie, okoliczności wszystko się na mnie sprzysięgło, że pomimo najusilniejszej chęci wyrwania się z Płocka, dla ucałowania rączek drogiej mi Pani, muszę tu pokutować jak Tantal lub Iksjon ${ }^{1}$ mitologiczny. Czas, co tu siedzę, zdaje mi się być wiecznością, bo niezawodnie dzień w Płocku ma więcej niż czterdzieści ośm godzin, jest to bowiem prawdą matematyczną, chociaż nie $\mathrm{z}$ matematycznych nauk wyciągniętą, że nie ma na kuli ziemskiej nudniejszego miejsca nad starożytną stolicę Książąt Mazowieckich [...]. Jeżeli na tamtym świecie chwile nudy będą do zasług liczone, to moja szala dobrego wszystkie moje błędy przeważy. (BZ 795, k. 312) ${ }^{2}$
\end{abstract}

W tak oryginalny sposób pisał o Płocku w 1844 r. jeden z nieco zapomnianych romantyków - Gustaw Zieliński, który w historii literatury zagościł głównie za sprawą swej powieści poetyckiej pt. Kirgiz. Inne utwory - poematy: Stepy, Samobójca, czy powieść Manuela, że o drobnych utworach lirycznych

Dr hab. MAŁGORZATA KRÓL, prof. KUL - Instytut Literaturoznawstwa Katolickiego Uniwersytetu Lubelskiego Jana Pawła II; adres do korespondencji: Al. Racławickie 14, 20-950 Lublin; e-mail: malgorzata.krol@kul.pl; ORCID: https://orcid.org/0000-0002-3691-1928.

${ }^{1}$ Iksjon - Kain mitologii, pierwszy morderca, który zabił swojego krewnego, Dejoneusa (teścia). Za karę został strącony do Tartaru, gdzie przykuto go do wiecznie obracającego się, płonącego koła (zob. np. Kopaliński 398-399).

${ }^{2} \mathrm{~W}$ odniesieniu wykorzystywanych rękopisów korzystano z zasad modernizacji przyjętych dla utworów połowy XIX stulecia. Modernizacja pisowni i interpunkcji została ograniczona do niezbędnego minimum - tzn. objęła tylko te zjawiska, które nie świadczą o języku autora i epoki. 
w ogóle nie wspomnę, pozostają zupełnie nieznane. A Gustaw Zieliński to niebanalny, XIX-wieczny Polak. Poeta, powieściopisarz, powstaniec listopadowy, zesłaniec, ziemianin, społecznik, bibliofil, mecenas kultury. Niniejszy tekst jest próbą wyjścia poza takie encyklopedyczne informacje. Oddania realiów barwnego, ale też niełatwego życia w połowie XIX wieku w Warszawie i na Mazowszu. Zanim jednak przejdę do odtwarzania codzienności ówczesnych warstw wyższych (a też kształtującej się inteligencji), warto przypomnieć, że Zieliński urodził się 1 listopada 1809 r. w Markowicach (obok Inowrocławia), a zmarł 23 listopada 1881 r. w Skępem. Uczył się w Toruniu, potem w Warszawie, by wreszcie trafić (w latach 1824-1827) do Szkoły Wojewódzkiej (tzw. Małachowianki) w Płocku. W 1827 r. zapisał się na Wydział Prawa i Administracji Uniwersytetu Warszawskiego. Studiował administrację, którą ukończył z tytułem magistra 20 lipca 1830 r. 29 listopada 1830 r. był w oddziale wspierającym belwederczyków. W 1831 r., chroniąc się przed konsekwencjami udziału w powstaniu, przeszedł granicę pruską, ale już w 1832 r., korzystając z amnestii, powrócił do kraju. Aby uniknąć służby w wojsku carskim, zajął się gospodarowaniem w wydzierżawionym od stryja folwarku Kierz. Rządy gospodarskie przekazal jednak ekonomowi, a sam oddał się literaturze. Niebawem, za pomoc rannemu partyzantowi z oddziału zaliwszczyków, został aresztowany. Wyrokiem sądu wojskowego z 29 lipca 1834 r. skazany na utratę praw publicznych, konfiskatę majątku i zesłanie do zachodniej Syberii. 1 września 1834 r. trafił do Tobolska. Tam i w Iszymie przebywał w latach 1834-1842. To wówczas zaistniał jako poeta. Najwybitniejszym utworem pochodzącym z tego czasu jest wspomniana już powieść poetycka pt. Kirgiz (wydana nakładem Teofila Glücksberga w Wilnie już w 1842 r.). W latach 1835-1842 powstały też, dziś niemal zapomniane: pisany $\mathrm{w}$ Tobolsku Samobójca (1835), dramat historyczny pt. Zbigniew (odrobinę wcześniejszy, bo z lat 1833-1839 - Nowy Korbut IX, 394), urywek starej legendy pt. Jan z Kepy (powst. 1841-1842, Iszym), powieść wschodnia Koń Beduina (1835-1840, Iszym), obrazek wschodni Antar (1835-1842, Iszym) oraz pierwsza część poematu opisowego pt. Stepy (1842, Iszym).

Gdy jesienią 1842 r. Zieliński wrócił do kraju, był entuzjastycznie witany jako dobrze rokujący literat. Niestety, ataki ze strony krytyki sprawiły, że pisał mało, a publikował wyłącznie utwory powstałe na Syberii. Drukowano go w Przegladzie Naukowym, Bibliotece Warszawskiej i lwowskich Rozmaitościach. Niebawem zupełnie odłożył literackie pióro, a czas wypełniły inne obowiązki. Już w 1847 r. objął po zmarłym stryju Józefie ogromny, ale bardzo zadłużony majątek Skępe. Ratując rodzinną spuściznę, nie zaniedbał działalności 
publicznej. Był członkiem Towarzystwa Kredytowego Guberni Płockiej (1850), od 1856 r. radcą Towarzystwa Kredytowego Ziemskiego, sędzią pokoju powiatu lipnowskiego. Wszedł w skład oddziału rolniczego przy Komisji Rządowej Spraw Wewnętrznych, był prezesem Towarzystwa Rolniczego w Płocku, a w 1858 r. współzałożycielem Domu Zleceń Rolniczych Płockich (Krajewski 2: 545). Pracę na rzecz gospodarstwa i kraju porzucił tuż przed powstaniem styczniowym, albowiem jak wielu powstańców listopadowych, sprzeciwiając się wybuchowi nowego zrywu, wybrał dobrowolną banicję i rozpoczął okres podróży po Europie. U schyłku życia został mecenasem kultury. Wspierał finansowo Bibliotekę Warszawska (gdzie był też redaktorem), Gazete Łęcka, wydanie Dzieł Kochanowskiego. Współfinansował budowę pomnika Adama Mickiewicza w Krakowie, wydanie przez Akademię Umiejętności Laudów dobrzyńskich (Kraków 1887), druk poezji Teofila Lenartowicza. W tym okresie życia ważniejsza, aniżeli literatura piękna, stała się historia. Napisał wiele prac historycznych - Starożytności dobrzyńskie, O Ziemi Dobrzyńskiej. Badania historyczne, Gród pokrzyżacki w Zarzeczewie w Ziemi Dobrzyńskiej oraz Obszar i granice zastawionego (r. 1391) przez Władysława Opolczyka terytorium Złotoryi (Zieliński 1874, 1861, 1911-1913). Za najważniejszą uznaje się Wiadomość historyczna o rodzie Świnków oraz rodowód pochodzacej od nich rodziny Zielińskich herbu Świnka (1880-1881). Zgromadził ogromny księgozbiór (liczący około 20 tys. tomów), stanowiący początek istniejącej do dziś Biblioteki im. Zielińskich przy TNP w Płocku. Dwukrotnie żonaty (Bieliński 460-461; Gerber 253; Polanowski 881-894; Krajewski 543-546). Z drugiego małżeństwa (z Anielą z Romockich) doczekał się jedenaściorga dzieci (Zofia, Karol, Władysław Apolinary, Ludwik Norbert, Jan Nepomucen, Ignacy, Adolf, Stanisław, Stefan, Kazimiera Gabriela, Kon-

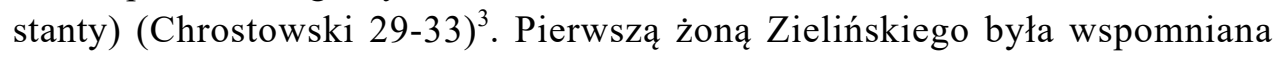
we wstępie „Pani” - Urszula z Romockich, a list pochodzi z okresu ich narzeczeństwa i zaczerpnięty został ze zbioru, który zawiera korespondencyjne świadectwa nie tylko ich wzajemnej fascynacji, dobrego, choć niełatwego i krótkiego wspólnego życia ${ }^{4}$, ale jest też dokumentem epoki. Dokumentem sporządzonym przez ważnego uczestnika XIX-wiecznego życia społecznego i kulturalnego.

\footnotetext{
${ }^{3}$ W dzieciństwie zmarli: Adolf, Ignacy, Stanisław, Stefan.

${ }^{4}$ Urszula, jedyna córka Stanisława Romockiego, po ojcu odziedziczyła Łążyn pod Ciechocinkiem. Ślub z Gustawem odbył się w 1844 r. Była matką trójki dzieci, z których dwoje (Maria i Stanisław) zmarło w dzieciństwie, pozostał przy życiu syn Józef (1845-1906), ofiarodawca zbiorów biblioteki skępskiej TNP. Zmarła w $1852 \mathrm{r}$.
} 
Urszula Romocka nie była pierwszą kobietą, którą pokochał Gustaw Zieliński. Jeszcze przed zesłaniem uczucie połączyło go z nieznaną bliżej Marią z Wymyślina. Sam kochanek chyba dość szybko zapomniał o tej fascynacji albo też, trafiwszy na zesłanie, nie będąc pewnym swego losu, nie chciał zwodzić kobiety ${ }^{5}$. Ona długo żyła wspomnieniami „lubej przeszłości”, o czym informował przebywającego na Syberii jeden z przyjaciół: „,...]Marynia z Wymyślina, $\mathrm{z}$ którą tak często i lubo wieczory w krzakach pod Kierzem przepędzałeś wzdycha za Tobą i jest Ci wierną jak Meluzyna" (BZ 797, k. 11). Nie znalazłam informacji, aby Zieliński poruszony doniesieniami przyjaciela próbował podtrzymać znajomość. Natomiast zaraz po powrocie z zesłania (1842) nie oparł się urokowi 17-letniej wówczas Urszuli Romockiej, do której na kilka miesięcy przed ślubem, tęskniąc, niebanalnie pisał:

To tylko dodać winienem, że duch mój, myśli moje ciągle dążą w stronę Łążyna i gdybym je mógł skrzydłami opatrzyć, byłabyś Pani w każdej chwili rojem skrzydlatych stworzeń otoczoną, może natrętnych jak komary, lecz piękniejszych niż Sylfy, którymi wyobraźnia dawnych poetów krainy powietrzne zaludniała. (BZ 795, k. 312)

Urszula mieszkała nieopodal Ciechocinka (w Łążynie), a uzdrowisko było miejscem jej częstych pobytów i spotkań z narzeczonym. Zieliński, prowadzący już wówczas niezwykle aktywne życie, nie znosił tego miejsca męczącego go swoim klimatem, monotonią, nudą. W Ciechocinku bywał tylko z uwagi na obecność ukochanej kobiety:

Myśli zaś moje ciągle dążą do miejsca, gdzie Pani przebywasz, bo Ciechocinek, aczkolwiek nudny, piaszczysty, ogołocony z wszelkich przyjemności i pięknej natury i co ważniejsza towarzystwa ludzi, w którego atmosferze do wyziewów mefitycznych, mady, wilgoci z ciągłych deszczów, łączy się jeszcze tuman plotek nad całym zakładem dominujacy. Ten Ciechocinek pomimo, że w tak niekorzystnym świetle muszę go sobie wystawić, należy przecie do najbarwniejszych obrazów mego życia. (BZ, 795, k. 314)

Należy żałować, że nie ma opisów, które wyszłyby spod pióra przebywającej tam kobiety. Śmiem przypuszczać, że byłyby dla kurortu zdecydowanie bardziej

\footnotetext{
${ }^{5}$ Taką decyzję podejmowało wielu młodych zesłańców, którzy swe narzeczone pozostawiali w kraju. Wyjątkową na tym tle (albo jedynie tak dobrze udokumentowaną) jest historia interkontynentalnego romansu Adolfa Januszkiewicza i Stefanii Ginowskiej, który ze zdwojoną siłą wybuchł w chwili, gdy ukochany, bo nawet jeszcze nie narzeczony - trafił na zesłanie. Zob. Cwenk 85-110.
} 
przychylne, albowiem Urszuli obcą była nuda, a na co jak na co, ale na brak adoratorów narzekać nie mogła:

À propos plotek ciechocińskich - muszę też Pani donieść jak niespracowanie i ciekawie śledzone są nie tylko słowa i czyny każdego, ale nieledwie myśli. Przybycie Kuźmińskiego, bywanie w domu Pani, częstsze niż u innych współbawiących w Ciechocinku, nareszcie ubranie jego: to jest biała chustka na szyi i biała kamizelka, gdy bywał u Pani, zwróciły uwagę niektórych osób. Zaczęto więc szeptać i z wniosku do wniosku utworzono historię, niezupełnie z prawdy ogołoconą. (BZ 795, k. 315)

Ciechocinek (w połowie XIX wieku maleńka wieś) w niczym nie przypominał znanego nam współcześnie uzdrowiska. Dopiero w 1827 r. powstała tu pierwsza tężnia, a jeszcze później, bo w 1836 r., udostępniono kąpiele lecznicze. Romocka miała więc szansę zażywać kąpieli i odbywać inhalacje.

Zieliński nie starał się być obiektywnym, co może wynikało z zazdrości o otaczających uroczą pannę adoratorów. Na marginesie warto dodać, że opisy miejsc, w których bywał, a podróżował dużo, niemal zawsze były dla odwiedzanych miast, miasteczek, wsi mało przychylne. Krytyczny był wobec Płocka, co ciekawe miejsca, z którym powinien czuć się związany (czego nie można powiedzieć o Ciechocinku). W mieście zdobywał wykształcenie. Jest bowiem jednym z bardziej znanych (obok m.in. bł. Honorata Koźmińskiego, ks. Idziego Benedykta Radziszewskiego) uczniów i absolwentów ważnej dla szkolnictwa średniego w kraju i to na przestrzeni wielu wieków słynnej Małachowianki, istniejącej nieprzerwanie od 1180 r. - jako szkoła parafialna, a następnie kolegium jezuickie (Grzybowski 6-9) ${ }^{6}$. Uczniem Szkoły Wojewódzkiej, bo tak się ówcześnie nazywała, był w latach 1824-1827, kiedy to funkcję rektora sprawował wybitny pedagog Kajetan Morykoni (Lachowicz 4). Ale ani Płock - Stolica Książąt Mazowieckich, ani ważny ośrodek naukowy ${ }^{7}$ nie doczekał się aprobaty młodego intelektualisty. O mieście zdawkowo pisał: „Płock nowości nie ma żadnych; jest tu jakaś koczująca trupa aktorów i dziś występują z jakąś wielką sztuką Moliera i Diderota - ale niestety pomimo zapału do sztuk pięknych nie mogę jej widzieć, bo czas mi bardzo drogi i list mój kończę, aby Pani nie nudzić” (BZ 795, k. 315), a niżej dodawał: „[...] za parę godzin opuszczam stolicę nudów, a niegdyś Książąt Mazowieckich". Warszawa też nie była dlań szczególnie atrakcyjna: „Pisałem Ci, że Warszawa jest nudna, cicha, pusta nawet, z prowincji niewiele kto się znajduje, bo hotele

\footnotetext{
${ }^{6}$ Co prawda, mało jest dokumentów poświadczających zależność tych szkół.

${ }^{7}$ Towarzystwo Naukowe Płockie rozpoczęło swą działalność już w 1820 r.
} 
drogie [...]" (BZ 795, k. 346). O ile stolica Książąt Mazowieckich, Warszawa, były dla Zielińskiego tylko nudne, bo „z rozrywek ogołocone”, miastem umarłym zwał Wilno, które

[...] jak było od lat wielu, tak i zastygło, nie widać żadnych nowych budowli, które by obudzenie się z letargu lub wzrost znamionowały. Widzieliśmy dwie główne ulice, to jest Wielką, która do Ostrej Bramy aż do placu Katedralnego dochodzi i Niemiecką. Pomiędzy głównymi ulicami jest mnóstwo ciasnych, brudnych zaułków, zamieszkałych głównie przez żydostwo i ich obrzydliwe kramiki. Te zaułki przypomniały mi getto w Rzymie. (BZ 795, k. 106)

Z czego może wynikać tak niekorzystny sposób opisywania miejsc? Wydaje się, że Zieliński najlepiej czuł się w domu, a los nieustannie płatał mu figle, zmuszając do odbywania znienawidzonych, a koniecznych podróży. Najpierw była to droga na zesłanie, potem liczne wyprawy „w interesach”, a u schyłku życia europejskie wojaże - dobrowolna banicja w okresie trwającego na ziemiach polskich powstania styczniowego. O odwiedzanych z konieczności miejscach nie potrafił przychylnie pisać. Jednak to właśnie podejmowanym $\mathrm{z}$ większego lub mniejszego przymusu podróżom zawdzięczamy bogatą korespondencję, którą, kierując do żony, starał się wypełnić czas rozłąki.

Listy Zielińskiego z lat czterdziestych przynoszą wizerunek szczęśliwego, dobrego młodego małżeństwa. Żona otrzymywała drobiazgowe relacje $\mathrm{z}$ wypraw małżonka, a nawet szczegółowe uzasadnienia podejmowanych najdrobniejszych decyzji. Zieliński dostrzegał tę korespondencyjną skrupulatność, a nawet $\mathrm{z}$ niej pokpiwał, w jednym z listów notując: „Otóż moja Urszulko tak szczegółowy masz opis mojego tu życia, że sądzę J. J. Rousseau z równą szczerością nie pisał swoich spowiedzi” (BZ 795, k. 331). W istocie można dojść do takiego wniosku, gdy ten, 35-letni mężczyzna z rozbrajającą szczerością, wręcz naiwnością, w jednej z przesyłek informował: „Ale, ale kupiłem sobie taki scyzoryk, że sam pióra temperuje, ale prócz Ciebie nikomu nie będzie wolno dotknąć" (BZ 795, k. 336), a w innej, ciesząc się z udanej, a znów nie tak częstej, podróży koleją pisał:

Dziś jeździłem koleją żelazną do Rudy, mil 6 za Warszawę. [...] Dość Ci powiem, że lecieliśmy jak wariaci, bo wiorstę drogi czyniliśmy w minutę. Zatem 12 mil z przystankami co mila i zabawieniem na miejscu godziny, zrobiliśmy w 3 godziny i trzy kwadranse. Cudowna jazda. Szkoda, że z Łążyna do Warszawy nie na kolei. (BZ 795, k. 340) 
Epistolografia Zielińskiego $\mathrm{z}$ tego okresu jest interesująca $\mathrm{z}$ jeszcze innego powodu. Jej ukierunkowanie na postać adresatki, radość, jaką sprawiały mu korespondencyjne rozmowy, przekłada się na lekkość pióra. Z przyjemnością czyta się fragmenty takie jak zacytowany niżej, w niczym nieprzypominające niedawnych jeszcze jeremiad zesłańca ${ }^{8}$. Zmieniona radykalnie sytuacja życiowa nadawcy znalazła odzwierciedlenie w stylu jego listów. Dystans, z jakim pisze o sobie i swoich kłopotach, w korespondencji z poprzedniego okresu był niespotykany. Barwny, dowcipny opis jednej z wieczorno-nocnych podróży, w którym język potoczny góruje nad literacką polszczyzną, to tylko jeden z reprezentatywnych przykładów tej stylowej rewolucji:

Wczoraj, opuściwszy Działyń, udałem się wprost do Piórkowa i o szóstej stanąłem. [...] Zabawiwszy do siódmej ruszyłem, ale dokąd?... Noc ciemna, droga niegodziwa, góry, wyrwy, kałuże, przepaście. [...] Tak więc trzy mile żółwim postępując krokiem, z piętnaście razy o włos nie skręciwszy karku lub mając w perspektywie zamiast noclegu rów napełniony wodą, dostałem się nareszcie blisko północy do Chrostkowa, gdzie nie tylko kury i ludzie, ale wszystkie psy herkulesowym snem zasnęły. Nie opisuję jak cały świat zbudziłem. (BZ 795, k. 340)

Jeszcze barwniejszy opis niedogodności podróżnych zostawił w liście nieco późniejszym:

Pisałem $\mathrm{Ci}^{9}$, że nająłem Żyda, który bryką i tęgimi trzema końmi miał mnie zabrać rano w niedzielę z Płocka, a odstawić na południe w poniedziałek do Warszawy [...]. Otóż inaczej się stało, przeprawiałem się pod Płockiem i lubo Wisła była jak morze, ale spokojna, przeto ani choroby morskiej, ani rozbicia nie doświadczyłem. Wylądowawszy w Radziwiu ${ }^{10}$, wsiadłem na brykę i owe obiecane rumaki, ale ujechawszy milę drogi bryka zaczęła skrzypieć, a Rosynaty ustały. Musieliśmy dać wytchnąć koniom w pierwszej żydowskiej karczmie, spotkanej na drodze. Tym sposobem szły rzeczy do Słubic, gdzie bym najął inną furmankę, gdyby można było dostać. Zresztą jakkolwiek pełen gniewu wniosłem, że kiedy konie trzy godziny podjedzą i odpoczną to choć do Sochaczewa dnia tego mnie dowleką. Ale był to dla mnie dzień feralny, wszystkie rachuby moje zawiedzione. Dojechawszy do Iłowa konie ustały, a bryka tak skrzypiała,

\footnotetext{
8 „Wprawdzie Stryj ostatnim listem swoim zapewnił mnie, że 1000 r. as. rocznie odbierać będę, lecz po odebraniu 325 już przeszło pół roku upłynęło, a tu ani kopiejki nie widać; pokazuje się, że nie masz teraz przy Stryju nikogo, coby mu o mnie przypominał. Co do mnie [...] wziąłem już sobie za prawidło, aby się nie przypominać, bo to ciągłe jęczenia, proszenie, przemawianie do wspaniałości lub litości, ma w sobie coś żebrackiego, a żebranie jest niezgodne ani z moim charakterem ani sposobem myślenia" (Chmielowski 142-143).

${ }^{9}$ List $\mathrm{z}$ tymi informacjami nie zachował się.

${ }^{10}$ Radziwie - dawna wieś, obecnie dzielnica Płocka.
} 
warczała, piszczała, że aż dostałem bólu głowy. Przejechawszy tym sposobem Giżyce, bo w nawiasie dodać muszę, że mój Borowski wyrżnąwszy ogromną gałąź pomagał okładać Rosynaty, co przyspieszyło biegu, nie mogłem dalej wytrzymać i spotkawszy Żyda, jednokonną bryką jadącego w tym co i ja kierunku, przesiadłem się w jego ekwipaż, klnąc Żydów i śmiejąc się z siebie, że tak się dałem złapać płockim hebrajczykom [...]. Koniec końców, żem dojechał o 8 wieczorem do Sochaczewa, jadąc z Płocka godzin 12. (BZ 795, k. 321)

Ten fragment doskonale wpisuje się w cały szereg listów-relacji z przygód podczas podróży bryczką czy dyliżansem ${ }^{11}$, wszystkich pisanych z dużym zacięciem epickim.

${ }^{11}$ Przykładem podobnej narracji jest, także sprawnie napisany, list-relacja z nie bez przygód odbytej podróży do Warszawy Onufrego Pietraszkiewicza: „Po wielu pokonanych trudnościach w najmowaniu koni dla świąt żydowskich, przybyłem do Warszawy 29 września. [...] Jechałem bryką krakowską kapelusz mając między nogami, a że dosyć byłem podróżą znużony drzemałem szczęśliwie, a jakiś łajdak z lasu zbliżył się uchwycił kapelusz; jakże się zawiódł sądząc, że mój kapelusz co mu przyniesie, niewiele się pożywił, ale mnie niewygodę wielką uczynił, bo nie miałem czym przykryć głowy i tak się na rogatkach meldowałem. [...] Biedna kieszeń musiała pokutować za to, żem drzemał jadąc" (Pietraszkiewicz, AF 718, k. 91-92). Wartość takich fragmentów dostrzegł przed laty W. Panas. W tekście „Jeździec niebieski. Magiczne miejsce” (biblioteka.teatrnn.pl/dlibra/dlibra/doccontent?id=20515. Dostęp 21.06.2020) dostrzegł niewykorzystaną literacką szansę, jaką dawały rozrzucone w korespondencji opisy podróżnych ekscesów. Pisał: „Naturalnie, chodzi o karetę. A ściślej rzecz biorąc: o to, co się w niej odbywa. Ależ pamiętamy doskonale: Emma Bovary, z woli autora cudzołoży w karecie. [...] To bez wątpienia najbardziej głośny w dziejach piśmiennictwa akt małżeńskiej zdrady. Ale jak wspaniale przedstawiony! Wprost zazdrość bierze. Rzecz jasna, pisarska. [...] Flaubert jest narratorem wyjątkowo perwersyjnym, gdyż skupia się wyłącznie na bardzo detalicznym opisie chaotycznej marszruty, «kołyszącej się jak okręt» karety, która przez dobre kilka godzin drążyła po mieście bez żadnego widocznego (dla postronnego obserwatora) celu. A co z Pietraszkiewiczem? On także jedzie karetą: w towarzystwie konduktora, jakiegoś trunkowego porucznika i nieszpetnej panienki. Od razu też zabrał się do umizgów, ale warunki miał niesprzyjające - za dużo świadków. Sytuacja poprawiła się wreszcie w Puławach, gdy wojskowy wysiadł, a konduktor zasnął. Wtedy: «[...] całowałem po dwa, trzy, sto i nie wiem, wiele razy, ściskałem białą i toczystą pierś; ileż to sporów, ile całusków, nim spięcie odwiązał, nim paski, uciskające suknię, zwolnił, nim kołnierzyk uchylił! [...] Wszakże ty i sam przyznasz, że dotąd nic wszetecznego, ale wielki krok do wszeteczności. Śledziłem, kędy się miłość kryje. Szymanowskiego świątynia śpiewa: Później zlata do kolan i tam znaleziona. Lecz tu już granica nie zlata [...] 'Będę płakać'. Jeden wyraz rozbraja Onufra, thumi ognie wszeteczne». Tylko tyle. [...] trudno wybaczyć, iż spaprał wyśmienity motyw literacki. [...] Miał szansę wprowadzić przynajmniej motyw do literatury. Gdyby zamiast rozwlekłego listu napisał jakąkolwiek powieść, byłby pierwszy. A tak, co Francuz wymyśli...". Żeby nie pozostać na jednym przykładzie. Spod pióra Zielińskiego też wyszły opisy bardziej ekstremalnych podróży. Jeden z drogi na zesłanie: „Wyobraź więc sobie, trójkę koni lecących bez opamiętania, trzęsącą po dyszlach telegę, od której na łokieć czasem w górę odskakiwałem - dalej do tego upał dnia i chmury pyłu nas okrywającego i duszącego, a jeszcze nie będziesz miał dokładnego wrażenia naszej podróży. Ból piersi z pewnym rodzajem kłocia połączony, potłuczenie i rozstrojenie całej fizycznej ciała budowy, było wypadkiem tej drogi. Jakeśmy ją minęli zdawało nam się, że nowe 
Częste wizyty Zielińskiego w Warszawie były konieczne z uwagi na skomplikowane sprawy majątkowe, które swe rozstrzygnięcia miały w tamtejszych sądach. Jeden z najbogatszych ziemian Mazowsza odziedziczony ogromy majątek musiał oddłużyć, niejednokrotnie $\mathrm{z}$ trudem uprzedzając działania komornicze. Czasem jednak to komornik był pierwszy:

Niepotrzebnie dozwoliłaś zajęcia ekwipaży [...]. Trzeba było dosłownie zastosować się do mojej instrukcji, że w Łążynie nic nie ma mojego, a zatem, że nie pozwalasz na żadną czynność, co uczyniwszy trzeba było wsiąść do powozu i pojechać, przykazawszy ludziom, aby nic komornikowi nie pokazali. [...]. Mogłabyś go odesłać do Lipna, do Czaplińskiego, aby sobie przejrzał intercyzę [...]. Jutro będzie w sądzie apelacyjnym sprawa o wstrzymanie egzekucji. Pojutrze najdalej wyjmę wyrok [...]. Jak to smutna rzecz, nie być winnym grosza, starać się z każdym jak najuczciwiej postępować i dlatego, że się dwóch procesuje, znosić szykany i odpowiedzialność. Z tego wyszedłszy tematu można by przyjść do bolesnych rezultatów, że nie warto w dzisiejszym, oświeconym wieku być uczciwym człowiekiem, bo utworzy się banda łotrów, którzy w dzień biały, na publicznej drodze otoczą cię, zrabują i jeszcze musisz być wdzięczny, bo ci życie zostawią. (BZ 795, k. 332)

W kolejnym dodawał: „Jeżeli więc przybył komornik Lubinkowski ${ }^{12} \mathrm{z}$ pomocą wojskową $[\ldots]$ to możesz mu śmiało dozwolić, nie daj mu tylko ani jeść, ani pić, niech go diabli wezmą" (BZ 795, k. 333). Najbogatszy człowiek na Mazowszu nie wiódł więc beztroskiego życia. Niedawny jeszcze literat i zakochany romantyk, w listach do młodej małżonki coraz częściej sięgał po kupiecką stylistykę: ,[...] wełnę sprzedałem łążyńską po 61 talarów centar. Tu Żydzi targują u mnie żyto i groch. Dają mi za żyto po $\mathrm{f}^{13}$. 14 , czy 15 za korzec war-

rozpoczęliśmy życie. Największemu memu nieprzyjacielowi nie życzyłbym podobnej przejażdżki. Cierpiący mizerere ozdrowiał, a kto wie czyby i umarły nie zmartwychwstał” (List zaginął, cyt. za: Chmielowski I: 64-65). Drugi, będący relacją z podróży do Wilna: „Co do obsługi dodać winienem, że od banhofu do hotelu mieliśmy powóz (kolaskę) z hotelu, zaprzężoną w dwa dzielne, ale wariackie konie. A że droga od banhofu do hotelu prowadzi z góry na dół i przez dość kręte i wąskie ulice więc lecieliśmy jakby nas diabli nieśli, zataczając się kolaską od rynsztoka do rynsztoka, powypadały nam rzeczy i kuferki nasze, żeśmy sami nie powypadali, karków nie pokręcili, ludzi lub dorożek nie roztrącili to wielka łaska Pana Boga. Przed hotelem konie jak mur stanęly i my odetchnęli. Za tę przyjemność policzono nam z rachunku 80 kopiejek" (BZ 795, k. 107).

${ }^{12}$ Kalendarzyk Polityczny na rok 1845 (F. Radziszewski) na s. 203 wymienia komorników guberni płockiej. Wśród nich są Lubinkowski Józef i Lubinkowski Andrzej - zapewne mowa o jednym $z$ nich.

${ }^{13}$ Łążyn (podobnie jak Płock) był początkowo w zaborze pruskim. Pewnie dlatego zwyczajową, a wspomnianą walutą są jeszcze (1845) talary i fenigi (Ihnatowicz 254). 
szawski, za groch po f. 22 z dostawą do Osieka. [...] Donoszę Ci, abyś wiedziała jak się regulować, gdyby kto miał chęć kupna [...]" (BZ 795, k. 328).

Codzienność w niczym nie przypominała naszych wyobrażeń życia ówczesnego literata. Mnóstwo czasu zabierały sprawy związane z zarządzaniem ogromnym majątkiem, o których szczegółowo, ale nie mniej barwnie i z małżeńską szczerością pisał Urszuli:

Dziś pracowałem jak wół w pługu dzień cały. Ułatwiłem kilka korespondencji i wyekspediowałem 61 czynszowników. U mnie biuro jak rządowe. Czterech pomocników ciągle gryzda ${ }^{14}$ i rachuje, a ja zgarniam monetę i kwestie rozstrzygam. Stoły pełne piór, papierów, ksiąg, atramentu, kałamarzów, piasku, podłoga jak śniegiem zasypana szczątkami kwitów. Nad tym wszystkim wznosi się mgła tytoniu, którego (wybacz) pozwalam sobie więcej nad pięć porcji, ale wiedz, że bez fajki żadnej ważniejszej czynności przedsięwziąć niepodobna. (BZ 795, k. 323)

Rozłąka, konieczność odzyskiwania zadłużonego majątku, codzienne troski - czy tylko to wypełniało życie niedawnego poety, a też mecenasa i miłośnika sztuk pięknych? Nie. Z listów wyłania się też wizerunek człowieka zafascynowanego teatrem. Człowieka, który po intensywnym dniu pracy wytchnienia szukał właśnie w warszawskich teatrach. A że Zieliński był korespondentem dość pedantycznym, obraz teatralnego życia stolicy rysuje się dosyć wyraziście.

Najczęściej bywał w Teatrze Rozmaitości. Pierwsza wizyta dała okazję zobaczenia dość „,...] głupiej sztuczki pt. Mina, córka Burmistrza ${ }^{15}$ podtrzymywanej grą Żółkowskiego" i farsy Nowy Rok (BZ 795, k. 330). Alojzy Żółkowski był $\mathrm{w}$ istocie $\mathrm{w}$ tym czasie szanowanym i cenionym aktorem („Encyklopedia teatru”). O jego sukcesie już następnego dnia donosił Kurier Warszawski: „Wczoraj (t. j. 7 kwietnia) w Teatrze Rozmaitości przywołani w czasie Miny JP Żółkowski 3-kroć i JP Śliwowska [...]” (nr 93, 1845: 445).

Późniejsze wizyty obfitowały w pozytywniejsze doznania estetyczne. Zieliński w tym samym teatrze miał okazję zobaczyć graną po raz pierwszy „nową komedyjkę Fredra pt. Dożywocie”, którą uznał za przewyborną, a wzmocnioną jeszcze niezrównaną grą nowego artysty Rychtera (BZ 795, k. 331). Równie entuzjastyczne były recenzje w lokalnej prasie. W Kurierze Warszawskim czytamy:

Jak po długiej niepogodzie przyjemniejszą zdaje się być łagodność powietrza, tak milsze było wczorajsze widowisko w Teatrze Rozmaitości, w którym po kilkuletniej prze-

\footnotetext{
${ }^{14}$ Gryzdać - bazgrać, niestarannie, ale szybko pisać (Binkowski).

15 J.S. Jasiński, Mina, córka burmistrza. Komedioopera w 2 aktach.
} 
rwie przedstawienia na tutejszej scenie dzieł nowych hr. Aleksandra Fredry dano wczoraj dotąd niewidzianą 3-aktową komedię Dożywocie. Bawiono się ciągle, oddawano należny hołd Autorowi, który utrwalił słynność naszej literatury scenicznej. Wesołe sceny składają całe to dzieło, a najcelniejszą ozdobą jest płynność wierszów, które wsławiły Aleksandra Fredrę; w tej komedii wiersz jest 8-mio sylabowy, tyle był przyjemny uchu słuchacza, ile wyborowa muzyka Rossiniego, ale z podwójną wartością, bo nie tylko słuch, lecz i umysł zajmował. JP Rychter już należący do rzędu artystów teatrów w Warszawie ${ }^{16}$ przedstawił najgłówniejszą rolę charakterystyczno-komiczną; we wszystkich scenach pomnażał zadowolenie publiczności, okrywany był oklaskami i 6-kroć przywoływany [...]. (nr 95, 1845: 454)

Z równie dobrym przyjęciem (,furorę robi”) spotkało się inne dzieło Fredry - komedia „pt. Zemsta za mur graniczny, gdzie Rychter jest nieporównany (BZ 795, k. 342)". Może zaskakiwać tytuł (Zemsta za mur graniczny), ale przypomnieć należy, że warunki ostrej cenzury carskiej ograniczały możliwości repertuarowe. Fredrowską Zemstę przemianowano więc na Zemstę za mur graniczny (libretto przygotował Z. Noskowski), a Papkina przezwano Papką, zacierając rosyjskie brzmienie nazwiska. Premiera miała miejsce 26 września $1845 \mathrm{r}$. (Szwankowski 112), Zieliński widział więc sztukę niewiele później. W tym samym teatrze oglądał Pannę mężatkę (BZ 795, k. 342), w Teatrze Wielkim Normę, która „się bardzo dobrze udała” (BZ 795, k. 344) - i to znów zdaniem wielu, albowiem w „Kurierze Warszawskim” czytamy: „Wczoraj w Wielkim Teatrze w czasie wybornie przedstawionej opery Norma przywołani JP Rywacka 3, JP Drobski 2-kroć [...]" (Kurier Warszawski, nr 269, 1845: 2). Był

[...] na wystawieniu Roberta Diabła. Signiora Rywacka śpiewała bardzo pięknie, oprócz głosu pięknego śliczna modulacja i metoda. Inni aktorowie jak Troszel, Drobski, Rivoli ${ }^{17}$ śpiewali bardzo dobrze, słowem zadowolony kompletnie wróciłem o wpół do dwunastej z teatru, pierwszy raz bowiem widziałem Roberta w komplecie, bo nic nie wypuszczono. (BZ 795, k. 335)

Wspominany przez Zielińskiego Robert Diabet (Robert le diable) to pięcioaktowa opera Giacomo Meyerbeera do libretta Eugène'a Scribe'a i Casimira Delavigne'a, której polska premiera miała miejsce w warszawskim Teatrze Wielkim 16 grudnia 1837 (Borkowska-Rychlewska 96). Zieliński widział więc sztukę dużo później. Wilhelm Troschel (Troszel), który tak dobre zrobił i na Zielińskim wrażenie, był ówcześnie gwiazdą sceny warszawskiej,

${ }^{16}$ Józef Franciszek Rychter (1820-1885). W okresie, z którego pochodzi list Zielińskiego, aktor pracował już w Warszawie (,Encyklopedia teatru”). 
a za jedną z jego wybitniejszych ról uważano tę z Roberta Diabła (Sowiński 387-388), nieustępującą poziomem od partii tytułowej tenora Juliana Drobskiego (135) czy Pauliny Rivoli (595).

Czy tylko wizyty w teatrze wypełniały wolny czas niedawnego literata? Zdecydowanie rzadziej, ale wspomina, o spotkaniach w ówczesnych warszawskich salonach:

Nie byłem jeszcze [...] u Łuszczewskich. Dziś spotkałem Łuszczewskiego i prosił, abym w poniedziałek był u nich. Może i będę. Wieczory pani Niny coraz więcej przybierają postać emancypacyjną - po jedenastej, gdy się damy rozjadą, gospodyni bierze cygaro i goście także i palą aż ciemno. Piszę, com słyszał, w poniedziałek naocznie się przekonam. (BZ 795, k. 335)

Salonom ówczesnej Warszawy i ich bywalcom, oglądanym z perspektywy prowincjonalnego literata i niedzisiejszego romantyka, a w latach czterdziestych człowieka dystansującego się od kręgów literackich, należy poświęcić zupełnie osobną rozprawę. Ta miała na celu ubarwienie biografii zapomnianego twórcy, który w świadomości odbiorców literatury XIX wieku dość niesprawiedliwie funkcjonuje hasłowo jako autor właściwie jednego tekstu. Może też po trosze mecenas kultury i społecznik, ale już zupełnie nie jako ciekawy epistolograf, którego zapisy korespondencyjne przybliżają stosunki gospodarczo-społeczne, realia kulturalne nie tylko ówczesnej stolicy, ale Mazowsza, a wraz z upływem czasu obejmują coraz to szerszy obszar - kraju, a potem Europy.

BIBLIGRAFIA

\section{PODMIOTOWA}

\section{Rękopisy}

Dział Zbiorów Specjalnych, Biblioteka im. Zielińskich w Płocku [BZ]

sygn. 795: Listy Gustawa Zielińskiego do Zielińskiej Urszuli z Romockiej (1844-1848), k. 312-346; sygn. 795: Listy Gustawa Zielińskiego do Erazma Wróblewskiego (1874-1888), k. 78-311;

sygn. 797: Korespondencja do Zielińskiego od następujących O-Z: Listy Zygmunta Ołowskiego do Gustawa Zielińskiego (1835-1853), k. 10-21.

Druki

Zieliński, Gustaw. „Starożytności dobrzyńskie”. Wiadomości Archeologiczne, t. 2, 1874, ss. 79-99.

Zieliński, Gustaw. „O Ziemi Dobrzyńskiej. Badania historyczne”. Biblioteka Warszawska, t. 3, 1861, ss. 233-285. 
Zieliński, Gustaw. „Gród pokrzyżacki w Zarzeczewie w Ziemi Dobrzyńskiej”. Zapiski Historyczne, t. 2, 1913, ss. 181-184.

Zieliński, Gustaw. „Obszar i granice zastawionego (r. 1391) przez Władysława Opolczyka terytorium Złotoryi". Zapiski Historyczne, t. 2, 1913, ss. 225-228.

Zieliński, Gustaw. Wiadomość historyczna o rodzie Świnków oraz rodowód pochodzącej od nich rodziny Zielińskich herbu Świnka. Wydawcy Gustaw i Jan Zielińscy, 1880-1881.

\section{PRZEDMIOTOWA}

Bieliński, Józef. „Gustaw Zieliński”. Królewski Uniwersytet Warszawski (1816-1831), t. 3, Skład Główny Gebethner i Wolff, [druk:] W. L. Anczyc i Spółka, 1907-1912, ss. 460-461.

Binkowski, Mirosław Kaźmiyrz. „Mój słownik gwary pałuckiej”, www.kazmiyrz.pl/file-15, mojslownik-gwary-paluckiej-wersja-pdf.pdf. Dostęp 17.09.2018.

Borkowska-Rychlewska, Alina. „Literackie metamorfozy «Roberta Diabła». O polskich wersjach libretta opery Giacoma Meyerbeera i dramatu Ernsta Raupacha”. Pamiętnik Literacki, z. 2, 2004, ss. 95-118.

Chmielowski, Piotr. Poezje Gustawa Zielińskiego poprzedzone życiorysem na podstawia listów poety skreślonym i ocena jego działalności przez [...], t. I-II, własność i wydanie rodziny (drukarz S. Buszczyński), 1901.

Chrostowski, Tadeusz. „Potomstwo Gustawa Zielińskiego”. Notatki Płockie, nr 4, 1981, ss. 29-33.

Cwenk, Małgorzata. „«[...] Każdy jej list zdaje mi się Sybir w raj przemieniać». Syberia Adolfa Januszkiewicza". Syberia infernalna - mity i oblicza rzeczywistości, red. Małgorzata Cwenk, Jan Trynkowski, Wydawnictwo KUL, 2014, ss. 85-110.

„Encyklopedia teatru”, www.e-teatr.pl/pl/osoby/41855.html. Dostęp 17.01.2017.

Gerber, Rafał. „Gustaw Zieliński”. Studenci Uniwersytetu Warszawskiego (1808-1831), Zakład Narodowy im. Ossolińskich, 1977, s. 253.

Grzybowski, Michał Marian. „Dziedzictwo i tradycja najstarszej szkoły płockiej”, malachowiacy.pl/ B2015/malach2015mini.pdf. Dostęp 07.07.2020.

Ihnatowicz, Ireneusz. Vademecum do badań nad historia XIX i XX wieku. Państwowe Wydawnictwo Naukowe, 1967.

Krajewski, Mirosław, oprac. „Gustaw Zieliński”. Nowy stownik biograficzny Ziemi Dobrzyńskiej, t. 2, Dobrzyńskie Towarzystwo Naukowe, 2014, ss. 543-546.

Lachowicz, Magdalena. „Gustaw Zieliński”. Pałuki i Ziemia Mogileńska, nr 946 (13/20), 2011, s. 4.

Piekarski, Tomasz. „Historia Radziwia”, www.tmr.plo.pl/tmr_pliki/historia/tmr_h.html. Dostęp 19.09.2019.

Pietraszkiewicz, Onufry. List do brata Jozefa, BU KUL, Archiwum Filomatów [AF], 718, k. 91-92.

„Polacy z wyboru. Rodziny pochodzenia niemieckiego w Warszawie w XIX i XX wieku”, www.polacyzwyboru.pl/bohaterowie/biogramy/wilhelm-karol-troschel--troszel. Dostęp 01.06.2020.

Polanowski, Tadeusz. „Gustaw Zieliński 1809-1881”. Obraz literatury polskiej XIX i XX wieku, seria III, t. 2, red. Maria Janion, Maria Denarłowicz, Marian Maciejewski, Wydawnictwo Literackie, 1988, ss. 881-894.

Słownik biograficzny teatru polskiego 1765-1965, red. Zbigniew Raszewski, Państwowe Wydawnictwo Naukowe, 1973.

Sowiński, Wojciech. Słownik muzyków dawnych i nowoczesnych: kompozytorów, wirtuozów, śpiewaków instrumencistów, lutnistów, organmistrzów, poetów lirycznych i miłośników sztuki muzycznej, 
zawierający krótki rys historyi muzyki w Polsce, opisanie obrazów cudownych i dawnych instrumentów z muzyka i portretem autora. Drukarnia E. Martinet, 1874.

Szwankowski, Eugeniusz. Teatry Warszawy 1765-1918. Państwowe Wydawnictwo Naukowe, 1979.

Śliwińska Irmina, Stanisław Stupkiewicz, Halina Gacowa. Bibliografia literatury polskiej „Nowy Korbut”, t. 9: Romantyzm: hasła osobowe P-Ż, uzupetnienia. Państwowy Instytut Wydawniczy, Wydawnictwo Literackie Zakład Narodowy im. Ossolińskich, 1972, s. 394.

\section{„OTÓŻ MOJA URSZULKO TAK SZCZEGÓŁOWY MASZ OPIS MOJEGO TU ŻYCIA, ŻE "SĄDZE J. J. ROUSSEAU Z RÓWNĄ SZCZEROŚCIĄ NIE PISAŁ SWOICH SPOWIEDZI" - OBRAZY ŻYCIA PRYWATNEGO I KULTURALNEGO \\ W LATACH CZTERDZIESTYCH XIX WIEKU NA PODSTAWIE KORESPONDENCJI GUSTAWA ZIELIŃSKIEGO}

Streszczenie

Gustaw Zieliński to poeta, powieściopisarz, powstaniec listopadowy, zesłaniec, ziemianin, społecznik, bibliofil, mecenas kultury, który współcześnie najczęściej kojarzony jest z najpopularniejszym swym tekstem, powieścią poetycką pt. Kirgiz albo encyklopedycznie, hasłowo. Wiadomo, że był mecenasem i miłośnikiem kultury, ale niewiele nadto. Artykuł jest próbą wyjścia, na podstawie epistolografii, poza suche fakty. Oddania realiów barwnego, ale też niełatwego życia w połowie XIX wieku w Warszawie i na Mazowszu. Próbą przypomnienia niebanalnego epistolografa, którego zapisy korespondencyjne przybliżają stosunki gospodarczo-społeczne, realia kulturalne nie tylko ówczesnej stolicy, ale i Mazowsza, a wraz z upływem czasu i zmieniającym się życiem osobistym autora - kraju i ówczesnej Europy.

Słowa kluczowe: Mazowsze; Warszawa; sytuacja społeczno-gospodarcza i kulturalna w zaborze rosyjskim; epistolografia

"THE DESCRIPTION OF MY LIFE, MY DEAR URSZULKA, IS SO DETAILED THAT, I PRESUME, ITS CANDOUR SURPASSES THAT OF J.J. ROUSSEAU'S CONFESSIONS": IMAGES OF INDIVIDUAL LIVES AND THE SOCIAL LIFE OF THE 1840s BASED ON GUSTAW ZIELIŃSKI'S CORRESPONDENCE

Su m m a r y

Gustaw Zieliński was a poet, novelist, November Insurgent, exile, landowner, social worker, bibliophile and patron of culture, who is nowadays most often associated with his most popular text, the poetic novel titled Kirgiz, or else as an entry in encyclopaedias. It is known that he was a patron and lover of culture, but nothing more can be said. This article is an attempt to present a broader view, based on epistolography, going beyond the bare facts, presenting the realities of a colourful, but also difficult, life in mid- $19^{\text {th }}$ century Warsaw and Mazovia. It is an attempt to remind us of the original epistologist, whose correspondence presents economic and social relations, and the cultural realities, not only of the capital of that time, but of the whole Mazovian region, and, with the passage of time and the changing personal life of the author, of both the country [Poland] and Europe of that time.

Keywords: Mazovia; Warsaw; socio-economic and cultural situation in the Russian partition; epistolography 

